\title{
Spatiotemporal Distribution of Diagenesis in Siliceous Clastic Rocks
}

\author{
Yan Ming ${ }^{1, a,{ }^{*}}$ \\ ${ }^{1}$ No.3 Oil Production Plant of Daqing Oilfield Company Ltd., Daqing 163113, China \\ aym06879@sina.com
}

\begin{abstract}
The spatial and temporal distribution characteristics of the diagenesis of the siliceous clastic sequence are controlled by a series of parameters in the early diagenesis, the middle diagenetic stage and the late diagenetic stage. The distribution of sedimentary facies, climate, detrital composition and relative sea level controlled the spatial distribution of the early diagenetic facies. The most important terrigenous sediments of early diagenesis include silicate dissolution and kaolinite formation, montmorillonite and calcareous conglomerate. In the marine and transitional sedimentary environments, early diagenesis includes carbonate precipitation, opal, microcrystalline quartz, iron containing silicates, sulfides and zeolites. The early diagenetic evolution of the ocean and over sediment developed in a predictable sequence. The middle diagenesis is affected by early diagenesis, such as temperature, pressure and composition of the basin brine. The retention time of sedimentary sequence under some burial conditions is the key to determine the time, range and mode of diagenetic change. In the middle ages, the diagenesis mainly consists of albite albite, chlorite and illite, smectite and kaolinite, and chemical compaction and carbonate cementation. Mid deep buried diagenesis still exists many questions: (1) the fluid flow and the dissolution reaction; (2) mutual transmission of mudstone and sandstone; (3) hydrocarbon diagenesis in sandstone; (4) in a fluid source and importance of secondary intergranular and diagenetic stage intragranular pore formation. The main changes in the percolation and dissolution of atmospheric water is the dissolution of kaolinite and carbonate cements in the tens to hundreds of meters below the surface.
\end{abstract}

Keywords: Spatiotemporal distribution; Diagenesis; Siliceous rocks

\section{Introduction}

There are many geochemical systems in the siliceous clastic rocks, which are controlled by the thermodynamics of temperature and the dynamic imbalance between pore water and minerals. In addition, the change of formation pressure and hydrostatic pressure have an important influence on the mechanical and chemical compaction, and have an influence on the porosity and permeability of the sediments and the scope and mode of the flowing fluid. The factors to be considered are helpful to the understanding of the spatial and temporal distribution of the siliceous clastic rocks, mainly due to the control of oil composition to the reservoir quality. There is sufficient evidence to show that diagenesis has an effect on the decrease of porosity and permeability. This paper focuses on the diagenetic change of the spatial and temporal distribution of the current development situation and the key argument of: (1) the transmission mode of mudstone and sandstone; (2) organic acids in diagenetic reaction; (3) the middle diagenetic reaction is affected by the influence of advection and general mass transfer.

The burial depth of the middle diagenetic reaction may be based on the history of burial thermal evolution. In many basins, the deep and middle diagenesis is affected by uplift and late diagenesis. It is difficult to determine the depth and time of diagenetic change.

\section{Spatial Distribution of Early Diagenetic Evolution of Terrigenous Sediments}

The spatial distribution of the early diagenetic evolution of terrigenous sediments is affected by climatic conditions, continental facies and sedimentary facies. In warm, semi humid and humid conditions of the sediments near the river, the unsaturated atmospheric water causes the dissolution of detrital silica (mainly lithic grains, feldspar and mica) and kaolinite precipitation. The spatial 
distribution of kaolinite is influenced by the number and distribution of detrital silica and the hydrodynamic conditions of the sand bodies. Particle dissolution and kaolinite formed in the most stable, with sediment permeability, such as proximity, channel sand body, but less in well sorted sandstone, siltstone, splay lacustrine facies in distal

On the contrary, in warm, arid to semi-arid conditions and at the end, the fluvio lacustrine facies and inter dune deposition, atmospheric water mixing is limited, resulting in montmorillonite clay, iron oxide, hydroxide, sulfate, potassium feldspar, zeolite, calcrete, silcrete. The spatial distribution of these cements is related to the interaction of subsurface fluid from the proximal to the distal regions of the mineral groundwater

In the remote sediments and arid climate, the percolation of silicon conglomerate as a condensate can continue for hundreds of meters, such as the Quaternary and modern sedimentary. The siliceous conglomerate of groundwater is made up of quartz and quartz to Boulder, and the distant sediment can reach thousands of meters in the transverse direction. Potassium feldspar grows around detrital feldspar, and the appearance of detrital feldspar is replaced and the intergranular crystals are deposited in the end stream. The changes of the distal sediments include the extensive distribution of felsic pyroclastic materials caused by the crystallization of K-feldspar, zeolite and montmorillonite

\section{The Relationship Between the Spatial Distribution of Early Diagenesis and Sequence Stratigraphy}

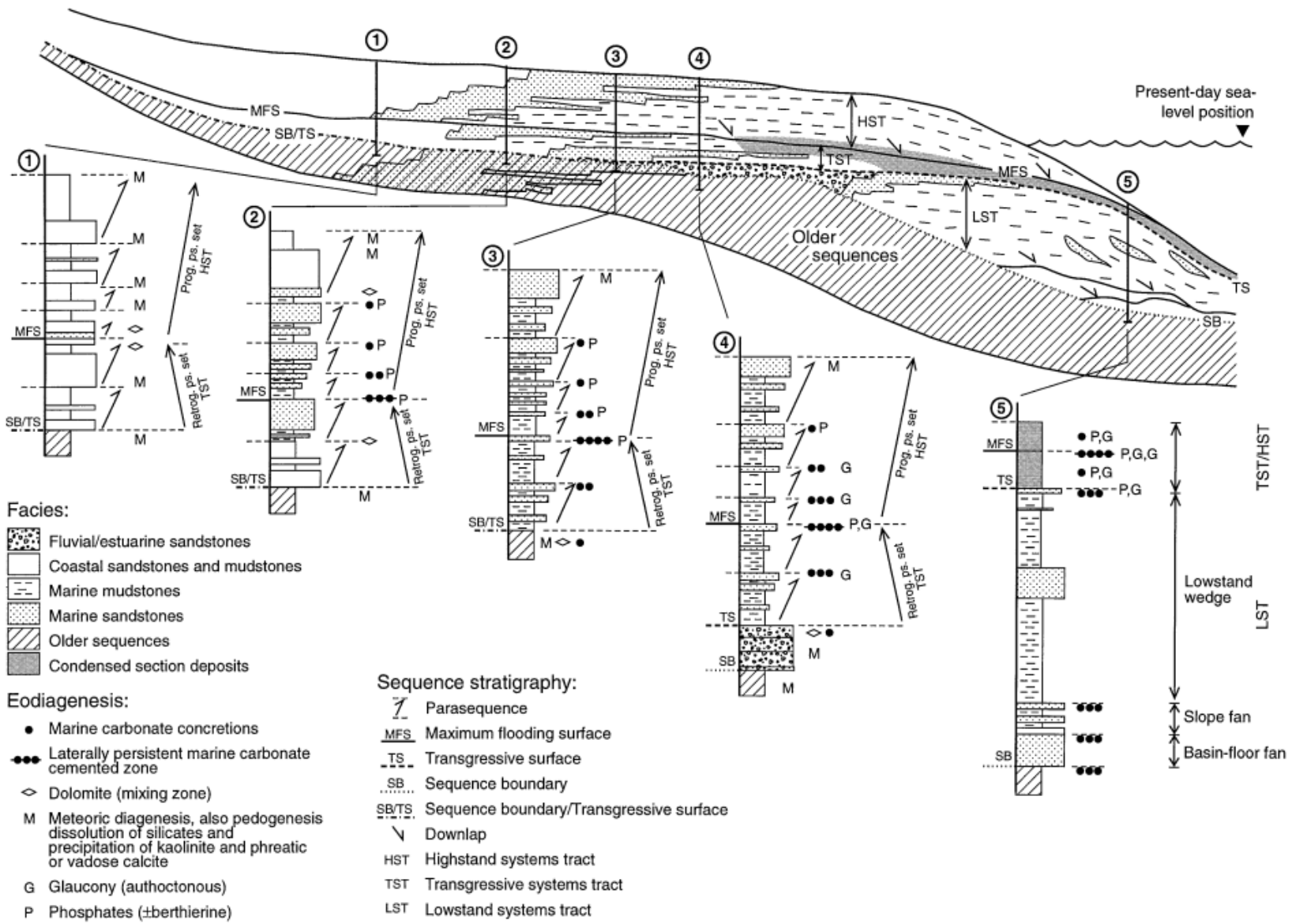

Fig. 1 The spatial distribution of eogenetic alteration

The change of relative sea level and sediment supply rate is the main factor controlling the water and water discharge events, which will help to predict the characteristics of sequence stratigraphy. These events control the location and dynamics of atmospheric water, mixed ocean atmosphere water and marine pore water. The variation of the pore water is controlled by the water and the water. The typical diagenetic change is related to the grade three or grade four sea-level change. At the five stage, 
the diagenetic changes can be identified, such as carbonate platform cementation and beach and foreshore sediments.

Transgressive and regressive composition will influence the sandstone clastic basin or basin, on the basis of particle proportion and spatial distribution. The non carbonate particles in the basin can only act as a result of a decrease in the sediment outside the basin. In addition, the particles in these basins were diluted and diluted. In the transgressive and highstand period, the sea covered slopes and shallow water carbonate origin, carbonate sediments in the deep slope of rapid deposition to produce rich carbonate debris or mixed Sandy Rock in transgressive and highstand system tracts. The clastic rock is usually plastic, and the mixed sandstone leads to the decrease of porosity and permeability. On the contrary, with the decrease of relative sea level and the exposure of the continental shelf, the carbonate formation is the lowest and the chemical denudation is the main one. These conditions lead to cementation of limestone and the role of Karst and the formation of bauxite on the shelf. As a result, there is little or no carbonate deposition in the lowstand system tract. As a result of mechanical compaction, carbonate cementation and porosity permeability decrease rapidly.

\section{Spatial and Temporal Distribution of Late Diagenesis}

Effect of unconformity late into factors including the time and space distribution of diagenesis: (1) water dynamics, according to the rise and fall of the sea; (2) climate; (3) the early and middle diagenetic porosity and permeability loss level; (4) the presence and absence of thick mudstone into this situation, to prevent the atmosphere water; (5) the presence of faults, which will provide the channel for meteoric water; (6) the duration of exposure; (7) mineral composition. The important late diagenetic changes caused by meteoric water erosion in siliceous clastic rocks include:

The dissolution of unstable framework grains, such as feldspar, mica, pyroclastic material, argillaceous clastic and heavy minerals. Different from the early diagenetic kaolinite, the late diagenetic kaolinite inhibits the growth of quartz, which is related to the carbonate cementation in the early and middle diagenesis.

Changes in cementation during early and middle diagenesis, such as calcite dissolution, dolomite, sulfate and feldspar growth, as well as oxidation of iron carbonate, chlorite and pyrite.

The formation of the soil and clay infiltration near the unconformity surface in the semi-arid climate, such as the formation of the calcium and iron crust, the silicon conglomerate and the iron conglomerate. In the late diagenesis, the permeability of the clay is covered in the middle diagenetic cementation, such as quartz.

\section{Conclusions}

Effect of siliceous clastic reservoir into a series of factors on the diagenesis of the spatial and temporal distribution include: (1) structural and thermal basin burial history; (2) the source of formation water in geochemical evolution; (3) the depositional environment and sedimentary facies; (4) climate conditions; (5) physical and the chemical properties of grain; (6) the relative sea level changes; (7) the number and reaction of organic matter; (8) the position of organic matter and organic matter maturity.

Although the diagenetic system is complex and multilateral, it is necessary to establish a model for the evolution of the global clastic rock reservoir. Reasonable model should be established on the basis of these: (1) dynamic database and thermodynamics of organic matter and non organic phase and reaction; (2) combined with microscopic observation (symbiotic relationship and fluid inclusion data) distribution and large wide range observation basin diagenetic change; (3) if the model is applied to the diagenesis the hydrocarbon exploration and development fields including comprehensive utilization of seismic interpretation and petrology and reservoir engineering. 


\section{References}

[1] Wilkinson M, Haszeldine R S, Fallick A E. Jurassic and cretaceous clays of thenorthern and central North Sea hydrocarbon reservoirs reviewed[J]. Clay Minerals, 2006, 41(1): 151-186.

[2] Weller J M. Compaction of sediments[J]. AAPG Bulletin, 1959, 43(2): 273-310.

[3] Walderhaug O. Kinetic modeling of quartz cementation and porosity loss in deeply buried sandstone reservoirs[J]. AAPG Bulletin, 1996, 80(5): 732-745.

[4] Surdam R C, Crossey L J. Integrated diagenetic modelinga: process-oriented approach for clastic systems[J]. Annual Review of Earth and Planetary Sciences, 1987, 15(2): 141-170.

[5] Schneider F, Hay S. Compaction model for quartzose sandstones application to the Garn Formation, Haltenbanken, mid-Norwegian continental shelf[J]. Marine and Petroleum Geology, 2001, 18(7): 833-848.

[6] Pittman E D, Larese R E. Compaction of lithic sands: experimental results and application[J]. AAPG Bulletin, 1991, 75(8): 1279-1299.

[7] Paxton S T, Szabo J O, Ajdukiewicz J M, et al. Construction of intergranular volume compaction curve for evaluating and predicting compaction and porosity loss in rigid grain sandstone reservoirs[J]. AAPG Bulletin, 2002, 86(12): 2047-2067.

[8] Midtbo R. E. A., Rykkje J. M., Ramm M. Deep burial diagenesis and reservoir quality along the eastern flank of the Viking Graben: evidence for illitization and quartz cementation after hydrocarbon emplacement [J]. Clay Minerals. 2000, 35(1): 231-241.

[9] Losh S, Walter L, Meulbroek P, et al. Reservoir fluids and their migration into the South Eugene Island Block 330 reservoirs, offshore Louisiana [J]. AAPG Bulletin. 2002, 86(8): 1463-1488.

[10] Lima R D, De Ros L R. The role of depositional setting and diagenesis on the reservoir quality of Devonian sandstones from the Solimes Basin, Brazil Amazonia[J]. Marine and Petroleum Geology, 2002, 19(9): 1047-1071.

[11] Jeffry D G. Origin and growth mechanism of authigenic chlorite in sandstones of the Lower Vicksburg Formation, South Texas[J]. Journal of Sedimentary Research, 2001, 71(1): 27-36. 